\title{
Microenxertia ex vitro para eliminação do vírus CABMV em maracujá-azedo
}

\author{
Leonardo Monteiro Ribeiro(1), José Ricardo Peixoto( ${ }^{(2)}$, Solange Rocha Monteiro de Andrade( ${ }^{(3)}$, \\ Rúbia Santos Fonseca ${ }^{(4)}$, Lorena Melo Vieira ${ }^{(1)}$ e Wilson Vicente Souza Pereira ${ }^{(1)}$
}

\begin{abstract}
(1)Universidade Estadual de Montes Claros, Departamento de Biologia Geral, Avenida Dr. Ruy Braga, s/no, Vila Mauricéia, CEP $39401-089$ Montes Claros, MG. E-mail: leomrib@hotmail.com, lorenamelovieira@hotmail.com, wvicentesp@yahoo.com.br (2)Universidade de Brasília, Faculdade de Agronomia e Medicina Veterinária, Campus Universitário Darcy Ribeiro, Asa Norte, CEP 70910-970 Brasília, DF. E-mail: peixoto@unb.br (3)Embrapa Cerrados, BR 020, Km 18, CEP 73310-970 Planaltina, DF. E-mail: solange@cpac.embrapa.br (4)Universidade Federal de Viçosa, Departamento de Biologia Vegetal, Avenida P.H. Rolfs, s/no, Campus Universitário, CEP 36570-000 Viçosa, MG. E-mail: rubiafonseca@hotmail.com
\end{abstract}

\begin{abstract}
Resumo - O objetivo deste trabalho foi avaliar diferentes meios de cultura, utilizados sobre o ponto da enxertia, na microenxertia ex vitro para a eliminação do Cowpea aphid-borne mosaic virus (CABMV), em plantas de maracujá-azedo (Passiflora edulis Sims f. flavicarpa Deg.). Ápices caulinares, provenientes de plantas infectadas, foram microenxertados em plântulas obtidas pela germinação de sementes em substrato comercial esterilizado. Foram conduzidos experimentos com a microenxertia realizada no hipocótilo e no epicótilo, e foram utilizados cinco meios de cultura, que diferiam na concentração de fitorreguladores, aplicados no local da enxertia. $\mathrm{O}$ índice médio de microenxertos com folha expandida foi de 27,22 e 32,22\%, quando a microenxertia foi realizada no hipocótilo e no epicótilo, respectivamente. Na microenxertia realizada no hipocótilo, não houve efeito da aplicação de meios de cultura. Na microenxertia realizada no epicótilo, o meio MS acrescido de $0,1 \mathrm{mg} \mathrm{L}^{-1}$ de AIB e $1 \mathrm{mg} \mathrm{L}^{-1} \mathrm{de} \mathrm{BAP}$ proporcionou 53,3\% de microenxertos com folha expandida, número superior aos demais tratamentos e maior desenvolvimento das brotações. A indexação realizada pelo teste ELISA indireto, 80 a 100 dias após a microenxertia, mostrou que $93 \%$ das plantas testadas não apresentavam vírus detectável.
\end{abstract}

Termos para indexação: Cowpea aphid-borne mosaic virus, Passiflora edulis, endurecimento dos frutos, local de enxertia.

\section{Ex vitro micrografting aiming the CABMV virus elimination in passion fruit plant}

\begin{abstract}
The objective of this work was to evaluate the effect of different culture media, used over grafting spot, in ex vitro micrografting, in order to eliminate the Cowpea aphid-borne mosaic virus (CABMV) in sour passion fruit plants (Passiflora edulis Sims f. flavicarpa Deg.). Cauline apexes, originated from infected plants, were micrografted in seedlings obtained by the germination of seeds in commercial sterilized substrate. Experiments were conducted with the micrografting performed on the hypocotyl and epicotyl using five culture media, which differed on their concentration of phytoregulators applied on the grafting spot. The average rate of micrografting showing expanded leaf was 27.22 and $32.22 \%$, when micrografting was performed on hypocotyl and epicotyl, respectively. In the micrografting performed on the hypocotyl, there was no effect of the culture media applied. In the micrografting performed on epicotyl, the MS medium supplemented with $0.1 \mathrm{mg} \mathrm{L}^{-1} 3$-indolbutiric acid (IBA) and $1 \mathrm{mg} \mathrm{L}^{-1}$ 6-benzylaminopurine (BAP) resulted in 53.3\% of micrografting showing expanded leaf, a number superior to the other treatments, and in a larger development of shoots. The indexing performed by the indirect ELISA test, within 80 to 100 days after micrografting, showed that $93 \%$ of the plants tested presented no detectable virus.
\end{abstract}

Index terms: Cowpea aphid-borne mosaic virus, Passiflora edulis, woodiness fruit, grafting spot.

\section{Introdução}

A cultura do maracujá-azedo (Passiflora edulis Sims f. flavicarpa Degener) tem sido prejudicada pela doença do endurecimento dos frutos, causada principalmente pelo Cowpea aphid-borne mosaic virus (CABMV), doença de etiologia viral mais importante no Brasil e que está disseminada na maioria das regiões produtoras (Nascimento et al., 2006). Essa enfermidade causa diminuição e deformação dos frutos e está associada à ocorrência de bolsas de goma no albedo. As plantas afetadas têm a produtividade e a vida útil diminuídas (Kitajima \& Rezende, 2001). A disseminação da virose tem impedido a utilização de métodos de propagação vegetativa, comuns em outros países, como a estaquia e a enxertia, que permitem a obtenção de clones precoces e uniformes (Lima \& Trindade, 2004). 
A microenxertia representa uma alternativa para a eliminação de vírus em espécies como o maracujazeiro, que apresentam baixa propensão ao cultivo in vitro de tecidos adultos (Navarro et al., 1975; Drew, 1991; Paz \& Pasqual, 1998; Mneney \& Mantell, 2001). A técnica consiste em se enxertarem ápices caulinares em portaenxertos micropropagados, cultivados in vitro (Paz \& Pasqual, 1998), e foi desenvolvida por Navarro et al. (1975). Biricolti \& Chiari (1994), ao utilizar ápices caulinares com 0,2 a $0,4 \mathrm{~mm}$ de comprimento, com no máximo quatro primórdios foliares, coletados de plantas de P. edulis f. edulis, não obtiveram regeneração no cultivo in vitro, apesar da sobrevivência dos explantes por longo período. No entanto, ao utilizar a microenxertia, esses autores obtiveram $50 \%$ de pegamento.

Oliveira et al. (2002) alteraram a metodologia básica de Navarro et al. (1975), para empregar procedimentos simples de assepsia e de cultivo que facilitassem a execução e reduzissem o custo do processo, e conseguiram eliminar o cultivo in vitro na obtenção dos porta-enxertos, por meio da semeadura e cultivo em substratos destinados à produção de mudas, previamente esterilizados. Esses autores observaram índices de pegamento de 34 a $79 \%$ em citros, de acordo com a combinação de genótipos doadores de ápices e portaenxertos. Como forma de aperfeiçoamento da técnica, tem-se estudado a aplicação localizada de meios de cultivo. Jeffree \& Yeoman (1983) demonstraram o efeito da utilização de meios de cultura, com o fitorregulador 6-benzilaminopurina (BAP), no ponto da enxertia, em citros. Starrantino \& Caruso (1998) constataram que o uso de BAP, aplicado no local da microenxertia, aumentou o potencial regenerativo dos tecidos e contribuiu para o incremento do índice de pegamento em citros. Nunes et al. (2005) comprovaram efeito do fitorregulador ácido 3-indolbutírico (AIB), aplicado no ponto de enxertia, sobre o desenvolvimento de microenxertos de macieira (Malus spp.).

Apesar dos trabalhos já realizados, a utilização prática da cultura de tecidos na passicultura ainda não é efetiva, no Brasil, e é necessário o aperfeiçoamento dessa tecnologia, para obtenção de maior eficiência na micropropagação e redução de custos, além da determinação de um protocolo para a eliminação de vírus (Junghans et al., 2004).

O objetivo deste trabalho foi testar um protocolo básico de microenxertia ex vitro, na eliminação do vírus
CABMV, e avaliar o efeito de meios de cultura, aplicados no local da microenxertia, sobre as brotações adventícias do porta-enxerto e desenvolvimento dos microenxertos.

\section{Material e Métodos}

Foram conduzidos dois experimentos: um para a microenxertia realizada no hipocótilo, e outro para a microenxertia realizada no epicótilo. No experimento com a microenxertia realizada no hipocótilo, plantas de maracujá-azedo (Passiflora edulis f. flavicarpa), obtidas a partir de sementes, com dois meses de idade, foram infectadas com vírus CABMV (Alfenas et al., 2005), em março de 2005. Dois meses após a inoculação dos vírus, todas as plantas apresentavam sintomas típicos da virose. Foi realizado o teste sorológico ELISA ("enzyme linked imunosorbent assay") indireto (Almeida, 2001), para confirmação da presença de CABMV. Quando as plantas estavam com um ano de idade (janeiro de 2006), foi realizada a coleta dos ápices caulinares.

Para a obtenção de porta-enxertos, foram utilizadas sementes da cultivar Rubi Gigante. Após a desinfestação por imersão em solução de $1 \%$ de hipoclorito de sódio, por $10 \mathrm{~min}$, seguida de tríplice lavagem em água destilada, as sementes foram plantadas em copos de plástico de $50 \mathrm{~mL}$, com substrato comercial Hortmax, previamente esterilizado em estufa a $150^{\circ} \mathrm{C}$ por 24 horas. Os recipientes foram mantidos à sombra, em condição de laboratório, e a microenxertia foi realizada de 21 a 28 dias após a semeadura.

Para a obtenção dos ápices caulinares, de cada planta matriz foi retirada a parte apical do ramo, com aproximadamente $3 \mathrm{~cm}$ de comprimento. Os ápices caulinares foram submetidos à desinfestação por imersão em solução de $0,25 \%$ de hipoclorito de sódio, por $10 \mathrm{~min}$, seguida por tríplice lavagem e imersão em água destilada, até a realização da microenxertia. Paralelamente, plantas destinadas a porta-enxertos, com 5 a $7 \mathrm{~cm}$ de comprimento, com folhas cotiledonares e uma ou duas folhas definitivas, foram desinfestadas por meio de pulverização com solução de hipoclorito de sódio $1 \%$ e, após $5 \mathrm{~min}$, lavadas com água destilada. Os portaenxertos foram dispostos horizontalmente sobre recipientes de acrílico tipo gerbox e fixados com fitacrepe nas folhas. Em seguida, com o auxílio de um estereomicroscópio e de uma seringa de plástico com agulha de $8 \mathrm{~mm}$ de comprimento e de calibre de $0,3 \mathrm{~mm}$, realizaram-se incisões, até a obtenção de uma abertura 
retangular no caule, na região hipocotiledonar, à altura aproximada de $3 \mathrm{~cm}$ acima do coleto. A abertura, de aproximadamente $8 \times 5 \mathrm{~mm}$, foi realizada no sentido longitudinal ao caule. Após a retirada dos tecidos da epiderme e de uma porção do córtex, foram aplicadas sobre a abertura duas gotas de solução antioxidante, composta pela associação de $100 \mathrm{mg} \mathrm{L}^{-1}$ de ácido ascórbico e $100 \mathrm{mg} \mathrm{L}^{-1}$ de ácido cítrico (Torres et al., 2001) .

Em seguida, um segmento apical de ramo fornecedor do ápice foi fixado por fita-crepe, em recipientes de plástico tipo gerbox, e sobre ele foi aplicada a solução antioxidante. Procedeu-se à retirada do ápice caulinar, de aproximadamente 0,2 a $0,4 \mathrm{~mm}$ de comprimento, constituído pelo meristema apical com dois a quatro primórdios foliares. $\mathrm{O}$ ápice foi transportado, com uso da agulha, e depositado na base da abertura, com a base dos tecidos do ápice em contato com o córtex do portaenxerto. Após esses procedimentos, foram aplicadas, sobre a microenxertia, os meios de cultura semi-sólidos, de acordo com os tratamentos, de modo a preencher a abertura e cobrir o ápice.

Depois da aplicação do meio de cultura, foi realizado o corte do caule do porta-enxerto, imediatamente acima da abertura da microenxertia, com auxílio de um bisturi. Os procedimentos foram repetidos nessa ordem em cada microenxertia. As plantas microenxertadas foram cobertas por um saco de polietileno, para manutenção de alta umidade, e foram mantidas sob temperatura ambiental em câmara clara, ajustada para fotoperíodo de 16 horas de luz, com irradiância de $25 \mu \mathrm{mol} \mathrm{m}{ }^{-2} \mathrm{~s}^{-1}$.

Os tratamentos foram constituídos por: ausência de aplicação de meios de cultura (controle); sais MS (Murashige \& Skoog, 1962), adicionados com 3\% de sacarose, $10 \mathrm{mg} \mathrm{L}^{-1}$ de tiamina, $1 \mathrm{mg} \mathrm{L}^{-1}$ de piridoxina, $1 \mathrm{mg} \mathrm{L}^{-1}$ de ácido nicotínico, $100 \mathrm{mg} \mathrm{L}^{-1}$ de mio-inositol, $2 \mathrm{~g} \mathrm{~L}^{-1}$ de Phytagel, com pH ajustado para 5,8 (daqui em diante referido como meio MS); meio MS acrescido de $0,1 \mathrm{mg} \mathrm{L}^{-1}$ de AIB; meio MS acrescido de $2 \mathrm{mg} \mathrm{L}^{-1}$ de BAP; meio MS acrescido de $0,1 \mathrm{mg} \mathrm{L}^{-1}$ de AIB e $1 \mathrm{mg} \mathrm{L}^{-1}$ de BAP; meio MS acrescido de 0,2 $\mathrm{mg} \mathrm{L}^{-1}$ de AIB e $2 \mathrm{mg} \mathrm{L}^{-1}$ de BAP. Os meios de cultura utilizados como adjuvantes foram preparados conforme recomendações de Torres et al. (2001) e autoclavados a $121^{\circ} \mathrm{C}$ por $20 \mathrm{~min}$.

Quinze dias após a microenxertia, as plantas foram avaliadas quanto à ocorrência de brotações adventícias do porta-enxerto, segundo a escala: 1 , ausência de gema no porta-enxerto; 2 , gema sem primórdios desenvolvidos no porta-enxerto; 3 , brotação com primórdios foliares no porta-enxerto; 4 , brotação com folha expandida no porta-enxerto. Após as avaliações das brotações, as gemas e brotações adventícias, quando presentes, foram retiradas com auxílio de um bisturi, para não comprometer o desenvolvimento do microenxerto. Aos 30 dias da microenxertia, as plantas foram avaliadas em relação ao percentual de microenxertos com folha expandida decorrente do desenvolvimento do ápice. Foi realizada, também, a avaliação do número médio de folhas expandidas por explante.

O experimento foi estabelecido no delineamento em blocos ao acaso, com seis tratamentos (meios de cultura aplicados sobre a microenxertia e controle) e seis repetições, cada uma constituída por cinco microenxertos. Para avaliação do efeito dos meios de cultura sobre as brotações adventícias do porta-enxerto, foi utilizado o teste Kruskal-Wallis. Para a avaliação da percentagem de microenxertos com folha expandida e do número médio de folhas, os dados foram submetidos à análise de variância e, quando constatada significância pelo teste $\mathrm{F}$, as médias dos tratamentos foram comparadas pelo teste de Tukey, a 5\% de probabilidade. Para o percentual de microenxertos com folha expandida, foi utilizada a transformação dos dados no modelo $\operatorname{arcsen}(\mathrm{x} / 100)^{0,5} \mathrm{e}$, para o número de folhas emitidas por microenxerto, foi utilizada a transformação dos dados no modelo $\mathrm{x}^{0,5}$.

$\mathrm{O}$ experimento com a microenxertia realizada no epicótilo foi executado nos mesmos moldes do anterior, com exceção da região do porta-enxerto em que foi realizada a microenxertia. Neste caso, a abertura feita no caule foi realizada imediatamente acima da região de inserção das folhas cotiledonares, à altura de aproximadamente $5 \mathrm{~cm}$ em relação ao coleto. Após a deposição do ápice e a aplicação do meio de cultura, foi realizada a excisão das folhas cotiledonares e das gemas axilares correspondentes, além da decapitação do epicótilo imediatamente acima da abertura da microenxertia. A condução e as avaliações foram semelhantes às do primeiro experimento.

Para a avaliação da eliminação do vírus CABMV, aos 30 dias da execução da técnica, as microenxertias viáveis foram retiradas das embalagens de polietileno e mantidas em câmara clara. Aos 45 dias, elas foram transferidas para copos de plástico de $200 \mathrm{~mL}$, com substrato comercial esterilizado para produção de mudas, e encaminhadas para casa de vegetação, com isolamento contra insetos. 
As primeiras 60 mudas obtidas foram utilizadas na indexação para o vírus CABMV, quando haviam passado 80 a 100 dias após as microenxertias. De cada planta, foi retirada uma folha da região apical, para a realização do teste sorológico ELISA indireto, tendo-se usado antisoro policlonal específico para o CABMV, conforme procedimentos descritos por Almeida (2001), a fim de se detectar a presença do vírus. Foi considerada positiva a amostra que apresentasse nível de absorbância duas vezes superior ao do controle negativo.

\section{Resultados e discussão}

No experimento com a microenxertia realizada no hipocótilo, observou-se, por meio do estereomicroscópio, intenso calejamento na região de enxertia, em todas as plantas, a partir do segundo dia da microenxertia. Esse fenômeno também foi observado por Biricolti \& Chiari (1994), após cinco dias da microenxertia de maracujároxo (P. edulis f. edulis). Aos sete dias, as observações realizadas permitiram constatar o início do desenvolvimento dos ápices. Os tratamentos não influenciaram significativamente o aparecimento de gemas adventícias, e o escore médio da brotação nos porta-enxertos foi de 1,88 .

Aos 30 dias, microenxertos mais desenvolvidos apresentavam folhas vigorosas e início do desenvolvimento do ramo. O percentual médio de microenxertos com folha expandida foi de $27,22 \%$. Não houve efeito significativo resultante da aplicação dos meios de cultivo sobre o percentual de microenxertos que apresentaram folha expandida (Tabela 1). O resultado da avaliação do número médio de folhas expandidas por microenxerto, aos 30 dias, evidenciou a média geral de 0,52 folhas emitidas por microenxerto. Nessa avaliação, também não foi constatada diferença significativa entre os tratamentos. A ausência de efeito dos meios de cultura pode ser atribuída à falta de competência dos tecidos do hipocótilo para a reação aos estímulos proporcionados, o que é dependente da condição morfo-fisiológica das plântulas (Drew, 1991; Taiz \& Zeiger, 2004). Embora estudos sobre a cultura de tecidos jovens, em espécies do gênero Passiflora, tenham demonstrado a resposta ao fitorregulador BAP (Biasi et al., 2000; Monteiro et al., 2000), ele não foi eficiente na indução da organogênese a partir de tecidos adultos de P. edulis f. edulis (Biricolti \& Chiari, 1994). Em estudos sobre a microenxertia em citros, Navarro et al. (1975) não encontraram efeito significativo da aplicação de AIB e BAP sobre o porta-enxerto, antes da implantação do ápice.

Também no experimento da microenxertia realizada no epicótilo, não foi possível observar efeito significativo dos tratamentos sobre o aparecimento de gemas adventícias, e sua brotação nos porta-enxertos apresentou escore médio de 2,47. Brotações adventícias do porta-enxerto foram relatadas como constantes em citros (Navarro et al., 1975). Os autores citados observaram efeito deletério delas sobre o desenvolvimento do explante. Navarro et al. (1975) recomendam a excisão das brotações, assim que sejam constatadas, e a adoção da incisão em forma de $\mathrm{T}$ invertido, por facilitar a identificação das brotações adventícias do porta-enxerto. Neste trabalho, verificouse que a abertura retangular também se mostrou apropriada para este fim.

O percentual de microenxertos com folha expandida, aos 30 dias, apresentou média de $32,22 \%$. Houve efeito significativo resultante da aplicação do meio MS acrescido de $0,1 \mathrm{mg} \mathrm{L}^{-1}$ de AIB e $1 \mathrm{mg} \mathrm{L}^{-1}$ de BAP, que proporcionou $53,3 \%$ de microenxertos com folha expandida, mas não diferiu do tratamento MS acrescido de $2 \mathrm{mg} \mathrm{L}^{-1}$ de BAP. Na avaliação do número de folhas expandidas por microenxerto, aos 30 dias, o tratamento MS acrescido de $0,1 \mathrm{mg} \mathrm{L}^{-1}$ de AIB e $1 \mathrm{mg} \mathrm{L}^{-1}$ de BAP apresentou resultado significativamente superior ao dos demais tratamentos (Tabela 1). Estudos realizados por

Tabela 1. Percentuais de microenxertos com folhas expandidas e número de folhas por microenxerto aos $30 \operatorname{dias}^{(1)}$.

\begin{tabular}{lccccc}
\hline Meio $^{(2)}$ & \multicolumn{3}{c}{ Local da microenxertia } \\
\cline { 2 - 3 } \cline { 6 - 7 } & \multicolumn{2}{c}{ Epicótilo } & & \multicolumn{2}{c}{ Hipocótilo } \\
\cline { 2 - 3 } \cline { 6 - 7 } & $\begin{array}{c}\text { Folhas } \\
(\%)\end{array}$ & $\begin{array}{c}\text { Número de } \\
\text { folhas }\end{array}$ & & $\begin{array}{c}\text { Folhas } \\
(\%)\end{array}$ & $\begin{array}{c}\text { Número de } \\
\text { folhas }\end{array}$ \\
\hline Controle & $26,7 \mathrm{~b}$ & $0,40 \mathrm{~b}$ & & $20,0 \mathrm{a}$ & $0,37 \mathrm{a}$ \\
MS & $26,7 \mathrm{~b}$ & $0,57 \mathrm{~b}$ & & $37,6 \mathrm{a}$ & $0,67 \mathrm{a}$ \\
MS + 0,1AIB & $30,0 \mathrm{~b}$ & $0,33 \mathrm{~b}$ & & $27,6 \mathrm{a}$ & $0,57 \mathrm{a}$ \\
MS + 0,1AIB + 1BAP & $53,3 \mathrm{a}$ & $0,97 \mathrm{a}$ & & $33,3 \mathrm{a}$ & $0,47 \mathrm{a}$ \\
MS + 0,2AIB + 2BAP & $23,3 \mathrm{~b}$ & $0,27 \mathrm{~b}$ & & $23,3 \mathrm{a}$ & $0,63 \mathrm{a}$ \\
MS + 2BAP & $33,3 \mathrm{ab}$ & $0,47 \mathrm{~b}$ & & $23,3 \mathrm{a}$ & $0,43 \mathrm{a}$ \\
\hline Média & 32,2 & 0,50 & & 27,2 & 0,52 \\
CV $(\%)$ & 18,3 & 21,4 & & 17,5 & 26,3 \\
\hline
\end{tabular}

(1)Letras iguais, na mesma coluna, não diferem entre si pelo teste de Tukey, a 5\% de probabilidade. ${ }^{(2)} \mathrm{MS}$ : sais MS acrescido de $3 \%$ de sacarose, $10 \mathrm{mg} \mathrm{L}^{-1}$ de tiamina, $1 \mathrm{mg} \mathrm{L}^{-1}$ de piridoxina, $1 \mathrm{mg} \mathrm{L}^{-1}$ de ácido nicotínico, $100 \mathrm{mg} \mathrm{L}^{-1}$ de mio-inositol e $2 \mathrm{~g} \mathrm{~L}^{-1}$ de Phytagel, com $\mathrm{pH}$ ajustado para 5,8 (meio MS); MS + 0,1 AIB: meio MS acrescido de $0,1 \mathrm{mg} \mathrm{L}^{-1}$ de AIB; MS + 0,1 AIB + 1BAP: meio MS acrescido de $0,1 \mathrm{mg} \mathrm{L}^{-1}$ de AIB e $1 \mathrm{mg} \mathrm{L}^{-1}$ de BAP; $\mathrm{MS}+0,2 \mathrm{AIB}+2 \mathrm{BAP}:$ meio $\mathrm{MS}$ acrescido de $0,2 \mathrm{mg} \mathrm{L}^{-1}$ de AIB e $2 \mathrm{mg} \mathrm{L}^{-1}$ de BAP; $\mathrm{MS}+$ 2BAP: meio MS acrescido de $2 \mathrm{mg} \mathrm{L}^{-1}$ de BAP. 
Jeffree \& Yeoman (1983) demonstraram o efeito da utilização, no ponto da enxertia, de meios de cultura com o regulador de crescimento $\mathrm{BAP}$, que proporcionaram aumento de 40 para $90 \%$ na taxa de pegamento, em citros. Starrantino \& Caruso (1988) constataram que o uso do fitorregulador BAP aumentou o potencial regenerativo dos tecidos e contribuiu para o incremento do índice de pegamento da microenxertia em citros de 73 para $91 \%$. Nunes et al. (2005) constataram que o fitorregulador AIB, associado ao meio MS aplicado no ponto de enxertia, promoveram maior desenvolvimento dos microenxertos de macieira (Malus spp.).

O meio básico MS suplementado com sacarose, vitaminas e mio-inositol, não afetou o resultado da microenxertia, em nenhum dos locais de realização. Esses resultados podem ser atribuídos à condição nutricional adequada do ápice, e à eficiência da solução antioxidante e da câmara úmida em evitar a deterioração dos tecidos. Apenas na microenxertia realizada no epicótilo, houve efeito significativo dos meios com fitorreguladores sobre o percentual de microenxertos com folha expandida e sobre o desenvolvimento dos microenxertos. Este resultado indica que, possivelmente, variações no grau de diferenciação dos tecidos afetaram a competência para a absorção e reação aos indutores e possibilitaram o efeito do tratamento meio MS suplementado com 0,1 $\mathrm{mg} \mathrm{L}^{-1}$ de AIB e $1 \mathrm{mg} \mathrm{L}^{-1}$ de BAP, quando a microenxertia foi realizada no epicótilo. Pio et al. (2001) avaliaram a organização anatômica dos tecidos de porta-enxerto de citros e demonstraram que ela é diferenciada a partir de $2 \mathrm{~cm}$ até a altura de $10 \mathrm{~cm}$, com a ocorrência de tecidos mais especializados no ápice. Esses autores afirmam que a interação dos ciclos celulares, tamanho e forma das células, exigência nutricional e ciclo de vida dos tecidos do explante e do porta-enxerto são fatores fundamentais para o sucesso da microenxertia.

A interação entre os níveis de AIB e BAP, em tecidos vegetais, é determinante para o controle do ciclo celular e da organogênese, e os níveis ótimos e inibitórios são variáveis de acordo com as condições anatômicas e fisiológicas dos tecidos (Taiz \& Zeiger, 2004). Há necessidade de mais estudos, com testes de diferentes concentrações de AIB e BAP, para se determinar a proporção ideal desses fitorreguladores.

Todas as plantas obtidas apresentaram-se assintomáticas em relação à virose do endurecimento dos frutos, aos 180 dias da microenxertia. O resultado do teste ELISA indireto, com uso do anti-soro policlonal específico para o CABMV, realizado nas primeiras 60 mudas obtidas, indicou que $93 \%$ delas encontravamse livres de vírus detectável.

Pelo critério de avaliação utilizado no teste ELISA foi possível detectar uma amostra positiva e três suspeitas. As causas da não eliminação de vírus podem ser atribuídas ao tamanho inadequado do explante e a características do patógeno. Paz \& Pasqual (1998) consideram a dimensão do ápice fundamental para a obtenção de plantas livres de vírus, e que é recomendável a utilização de ápices acompanhados de dois primórdios foliares, com aproximadamente $0,15 \mathrm{~mm}$, o que pode limitar substancialmente o pegamento.

Os resultados obtidos neste trabalho evidenciam que a microenxertia ex vitro, em maracujá-azedo, é viável e pode atingir índices compatíveis com a microenxertia in vitro, mesmo com a utilização de explantes com tamanho adequado à eliminação de vírus. Paz \& Pasqual (1998) afirmam que é comum, na microenxertia in vitro em citros, taxas de pegamento que variam de $2 \%$, quando se utilizam ápices com 0,05 mm de comprimento, a 50\%, quando se utilizam ápices com seis primórdios foliares. Raharjo \& Litz (2005) testaram a microenxertia em abacateiro (Persea americana), em condição in vitro e ex vitro, e observaram que os resultados referentes ao pegamento foram próximos e que as brotações obtidas na microenxertia ex vitro apresentaram maior desenvolvimento do que as obtidas na microenxertia in vitro.

\section{Conclusões}

1. Quando a microenxertia é realizada no hipocótilo, não há efeito da aplicação de meios de cultura sobre seu sucesso.

2. Quando a microenxertia é realizada no epicótilo, o meio MS suplementado com $0,1 \mathrm{mg} \mathrm{L}^{-1}$ de AIB e $1 \mathrm{mg} \mathrm{L}^{-1}$ de BAP proporciona o maior índice de microenxertos com folha expandida.

3. A ocorrência de brotações adventícias nos portaenxertos não é influenciada pelos meios de cultura, independentemente do local de realização da microenxertia.

4. A técnica da microenxertia é viável para a eliminação do vírus CABMV e para a limpeza clonal do maracujá-azedo. 


\section{Referências}

ALFENAS, P.F.; BRAZ, A.S.K.; TORRES, L.B.; SANTANA, E.N.; NASCIMENTO, A.V.S. do; CARVALHO, M.G. de; OTONI, W.C.; ZERBINI, F.M. Transgenic passionfruit expressing RNA derived from cowpea aphid-borne mosaic virus is resistant to passionfruit woodiness disease. Fitopatologia Brasileira, v.30, p.33-38, 2005.

ALMEIDA, A.M.R. de. Detecção e quantificação de vírus pelo teste de ELISA. In: ALMEIDA, A.M.R.; LIMA, J.A. de A. Princípios e técnicas de diagnose aplicados em fitovirologia. Londrina: Embrapa Soja; Brasília: Sociedade Brasileira de Fitopatologia, 2001. p.63-84.

BIASI, L.A.; FALCO, M.C.; RODRIGUEZ, A.P.M.; MENDES, B.M.J. Organogenesis from internodal segments of yellow passion fruit. Scientia Agricola, v.57, p.661-665, 2000.

BIRICOLTI, S.; CHIARI, A. Meristem culture and micrografting of Passiflora edulis f. edulis. Advances in Horticultural Science, v.8, p.171-175, 1994.

DREW, R.A. In vitro culture of adult and juvenile bud explant of Passiflora species. Plant Cell, Tissue and Organ Culture, v.26, p.23-27, 1991.

JEFFREE, C.E.; YEOMAN, M.M. Development of intercellular connections between opposing cells in graft union. New Phytologist, v.93, p.491-509, 1983.

JUNGHANS, T.G.; SOUZA, A. da S.; KOBAYASHI, A.K. Cultura de tecidos em maracujazeiros. In: LIMA, A. de A.; CUNHA, M.A.P. Maracujá: produção e qualidade na passicultura. Cruz das Almas: Embrapa Mandioca e Fruticultura, 2004. p.97-106.

KITAJIMA, E.W.; REZENDE, J.A.M. Enfermidades de etiologia viral e fitoplasmática. In: BRUCKNER, C.H.; PICANÇO, M.C. Maracujá: tecnologia de produção, pós-colheita, agroindústria, mercado. Porto Alegre: Cinco Continentes, 2001. p.277-282.

LIMA, A. de A.; TRINDADE, A.V. Propagação. In: LIMA, A. de A.; CUNHA, M.A.P. da. Maracujá: produção e qualidade na passicultura. Cruz das Almas: Embrapa Mandioca e Fruticultura, 2004. p.109-116.

MNENEY, E.E.; MANTELL, S.H. In vitro micrografting of cashew. Plant Cell, Tissue and Organ Culture, v.66, p.49-58, 2001.

MONTEIRO, A.C.B. de A.; HIGASHI, E.N.; GONÇALVES, A.N.; RODRIGUEZ, A.P.M. A novel approach for the definition of the inorganic medium components for micropropagation of yellow passionfruit (Passiflora edulis Sims. f. flavicarpa Deg.). In Vitro Cellular and Development Biology, v.36, p.527-531, 2000.
MURASHIGE, T.; SKOOG, F. A revised medium for rapid growth and bioassays with tobacco tissue cultures. Physiologia Plantarum, v.15, p.473-497, 1962.

NASCIMENTO, A.V.S.; SANTANA, E.N.; BRAZ, A.S.K.; ALFENAS, P.F.; PIO-RIBEIRO, G.; ANDRADE, G.P.; CARVALHO, M.G.; ZERBINI, F.M. Cowpea aphid-borne mosaic virus (CABMV) is widespread in passionfruit in Brazil and causes passionfruit woodiness disease. Archives of Virology, v.151, p.17971809, 2006.

NAVARRO, L.; ROISTACHER, C.N.; MURASHIGE, T. Improvement of shoot-tip grafting in vitro for virus-free citrus. Journal of the American Society for Horticultural Science, v.100, p.471-479, 1975.

NUNES, J.C.O.; ABREU, M.F. de; DANTAS, A.C. de M.; PEREIRA, A.J.; PEDROTTI, E.L. Morphologic characterization in apple micrografts. Revista Brasileira de Fruticultura, v.27, p.8083, 2005.

OLIVEIRA, I.V.M.; DAMIÃO FILHO, C.F.; CARVALHO, S.A. de. Enxertia em citros por substituição de ápice caulinar. Revista Brasileira de Fruticultura, v.24, p.744-747, 2002.

PAZ, O.P. da; PASQUAL, M. Microenxertia. In: TORRES, A.C.; CALDAS, L.S.; BUSO, J.A. (Ed.). Cultura de tecidos e transformação genética de plantas. Brasília: Embrapa-CNPH, Embrapa-SPI, 1998. v.1. p.147-159.

PIO, R.; CASTRO, E.M. de; RAMOS, J.D.; GAVILANES, M.L.; RIBEIRO, W.G. Características anatômicas de porta-enxertos de citros para microenxertia em diferentes alturas. Ciência e Agrotecnologia, v.25, p.848-852, 2001.

RAHARJO, S.H.T.; LITZ, R.E. Micrografting and ex vitro grafting for somatic embryo rescue and plant recovery in avocado (Persea americana). Plant Cell, Tissue and Organ Culture, v.82, p.1-9, 2005.

SAS INSTITUTE. SAS: user's guide: statistics version. Cary: SAS Institute, 1990. 846p.

STARRANTINO, A.; CARUSO, A. The shoot-tip grafting technique applied in citriculture. Acta Horticulturae, v.227, p.101-103, 1988.

TAIZ, L.; ZEIGER, E. Fisiologia vegetal. Porto Alegre: Artmed, 2004. 719p.

TORRES, A.C.; BARBOSA, N.V.R.; WILLADINO, L.; GUERRA, M.P.; FERREIRA, C.F.; PAIVA, S.A.V. de. Meio e condições de incubação para cultura de tecidos de plantas: formulações de meios para a cultura de tecidos de plantas. Brasília: Embrapa Hortaliças, 2001. 20p. (Embrapa Hortaliças. Circular Técnica, 24). 